\title{
Ignazio Camarda
}

\section{Paeonia sandrae (Paeoniaceae) species nova of Sardinia and relationship with peonies of Corsica and Sicily}

\begin{abstract}
Camarda, I.: Paeonia sandrae (Paeoniaceae) species nova of Sardinia and relationship with peonies of Corsica and Sicily. — Fl. Medit. 25: 127-136. 2015. — ISSN: 1120-4052 printed, 2240-4538 online.

A new species of peony from the Sardinia island named Paeonia sandrae has been described. Relationship with $P$. morisii from Sardinia, P. corsica from Corsica and P. mascula from Sicily are discussed, highlighting their morphological and caryological differences and affinities.

Key words: vascular flora, new species, taxonomy, comparison.
\end{abstract}

\section{Introduction}

The genus Paeonia is widespread in the Mediterranean area with a complex of species, subspecies and varieties (Stern 1944, 1946; Cullen \& Heywood 1964a, 1964b; Akeroyd 1993 ) but its knowledge is not fully satisfactory, despite recent important studies (Cesca \& al. 2001; Arrigoni 2006; Hong 2005; Hong \& Wang 2006; Schmitt 2007; Hong 2010) that have dealt with the problem in depth. In particular, peonies in the Sardinia and Corsica islands still present some gaps in the assessment of their status.

\section{Materials and Methods}

The genus Paeonia is largely widespread in mountain areas of Sardinia, especially in the inner regions, regardless of the substrate. In the hills and lower plains it shows a clear preference for volcanic fresh soil. In any case, peonies like sunny spots, but they can also be sporadically found under deciduous and, at times, in evergreen oak forests.

In the Island, first specimens were collected by Moris (1837) who regarded them as $P$. corallina var. pubescens, Briquet (1910) on the basis of hairiness distinguished P. coralli$n a$ var. pubescens Moris in Sardinia and P. corallina var. leiocarpa Cosson in Corsica.

Fiori (1923) classified the Sardinian peonies as P. mascula var. russoi (Biv.) Fiori. On the contrary, Negodi (1931), distinguished three varieties (typica, mascula and angustata) of Paeonia officinalis subsp. corallina Retz. 
Charrier (1963) described some white-flowered specimens found in the Arco Correboi of the Gennargentu mountain as Paeonia officinalis f. barbaricina; later Cullen and Heywood (1966) indicated the Sardinian plants as subspecies [P. mascula subsp. russoi (Biv.) Cullen \& Heywood].

P. mascula subsp. russoi (Biv.) Cullen et Heywood and P. coriacea Boiss. have been recorded by Pignatti (1982) as synonyms of $P$. corsica Sieber ex Tausch for its glabrous follicles, but Sardinian exsiccata of this entity are missing in FI!, SS! and Sassa!

Both Hong \& Wang (2006) and Schmitt (2007) mention P. corsica as a specimen collected by Reverchon at the Limbardo [=Limbara today] mountain, but never found by me, while I found there specimens attributable to P. morisii.

Thanks to the work of Cesca \& al. (2001), great attention has been drawn on the Paeonia genus in Sardinia. They revised P. mascula subsp. russoi (Biv.) Cullen \& Heywood as a new diploid species named Paeonia morisii endemic to Sardinia and Corsica and their conclusion has been confirmed by their later work (Passalacqua \& Bernardo 2004).

The finding in the central-north-western Sardinian mountains of any populations with several well distinct characters from $P$. morisii and $P$. corsica, has requested a comparative analysis with these entities in order to define their correct taxonomic attribution.

\section{Results}

Passalacqua \& Bernardo (2004) remark that literary historical data are difficultly interpretable, because of the origin of specimens is often unclear in relation to the number of chromosomes. For Italian peonies, Cesca \& al. (2001) indicate the Paeonia mascula s. 1. complex as diploid $(2 n=10)$ or tetraploid $(2 n=20)$ according to more recent works, that also discussed the morphological distinction between $P$. mascula subsp. russoi and $P$. morisii and the significant differences on the chromosome number: $2 n=20$, in the Sicilian plants against $2 n=10$ of the studied Sardinian populations of the Gennargentu mountain. The diploid status has been confirmed (Becca \& Camarda ined.) for population of other localities of Central Sardinia.

Hong (2005) and Hong \& Wang (2006) also consider P. morisii as a simple synonym of $P$. corsica and the sole species of Sardinia, widespread also in the Ionian Islands and in continental Greece, changing its status as Cyrno-Sardinian endemic species. Hong (2010) renew this opinion in the monography on Peonies of the world. On the contrary, Schuessel \& Jeanmonod (2006) consider $P$. corsica the most widespread species in Corsica and indicate also the presence of $P$. morisii as a different species, giving full autonomy and taxonomic validity to this entities. Hong and Wang's theory, is contested also by Schmitt (2007, and 2008 in litteris,), who regards the two entities morphologically and caryologically distinct, being $P$. morisii diploid and $P$. corsica tetraploid. Moreover, the herbarium specimens analysed or collected in Sardinia by these authors take into consideration plant living only in the central-southern and M. Limbardo (=Limbara) areas, but not in the central-northern area of the island. Schmitt (2007) indicates also the rare presence of $P$. mascula subsp. mascula in Corsica.

Under these considerations, it appears clear that the taxonomical controversy could be considered concluded, but Schmitt (2007) cites also P. revelieri Jordan in Jordan \& 
Fourreau (1903). as previous synonym to P. corsica. So that, further investigations appear necessary to define the correct nomenclature of this species or to indicate it as nomen conservandum.

The peony's populations of central and N-W Sardinian mountains, significantly differ from P. morisii. In fact, the individuals present $2-8$ stems (2-15 in P. morisii), a leaf-number of 3-7 totally glabrous, woolly carpels first erect and strongly recurvate at maturity with spherical larger seeds, an overlooked but important character, when compared to P. morisii (Fig. 3).

The chromosome number, presents a tetraploid status $(2 n=20)$, unlike $P$. morisii is diploid and the analysis of the caryogramme appears devoid of the typical satellite of $P$. morisii (Becca \& Camarda ined.). Furthermore, there is a significant difference in phenology, flowering 15-20 days later than the nearest, but not mixed with other populations of P. morisii. Other remarkable differences from P. morisii, are in the shape and size of petals which are longer and spatulate instead of ovate, and purple instead of whitish to pink colour and longer lanose hairs. A comparison with $P$. corsica shows similar significant differences regarding the shape of carpels, totally glabrous, not recurvate, smaller seeds and narrower leaves in this species. The greatest affinity is with $P$. mascula but differing by the number of carpels, length and size of the Sicilian specimens.

Therefore, Sardinian populations can be considered belonging to a new endemic species that I indicate Paeonia sandrae.

\section{Paeonia sandrae Camarda, sp. nova}

Typus - Holotypus: Sardinia : Bolotana, Loc. Camorra, Lat. 40 360554-Long. 8 870270, $910 \mathrm{~m}$ a.s.1, open wood of Quercus pubescens, 5.V.2015, I. Camarda s.n., SS!; Isotypi in FI! and PAL!

Iconography - Fig. 1. Original drawn by the author.

Diagnosis - Paeonia sandrae differt a Paeonia morisii Cesca, Bernardo et Passalacqua petalorum, folliculorum et seminum magnitudine, foliis glaberrimis, magnitudine et forma petala, folliculis dense pilosis-lanosis, fortiter recurvatis in fructu maturo et numero chromosomatico. Differt a Paeonia corsica Sieber ex Tausch foliarum, folliculorum, seminum magnitudine et indumento. Differt a $P$. mascula subsp. mascula numero foliolarum large ovatarum, a numero folliculis validioribus atque fortiter recurvatis.

Origin of the name - The species is named after my daughter Sandra.

Description - Perennial, herbaceous, cespitose plant, with (1)-3-8 smooth branches of 60-100 cm length with a short rhizome having robust and fusiform or carrotshape roots (until $30 \mathrm{~cm}$ long); buds covered by several bracts, before pink and after purplish, 3-4.5 cm long. Stems erect cylindrical or with weakly subangular streaks, glabrous, greenish to purplish every one containing 1 flower. Leaves 3-5 with robust petiole, totally glabrous in every part, from 25 until $60 \mathrm{~cm}$ of length, lower ones triternate with 9-25 leaflets broadly ovate, obovate, elliptical or grad- 


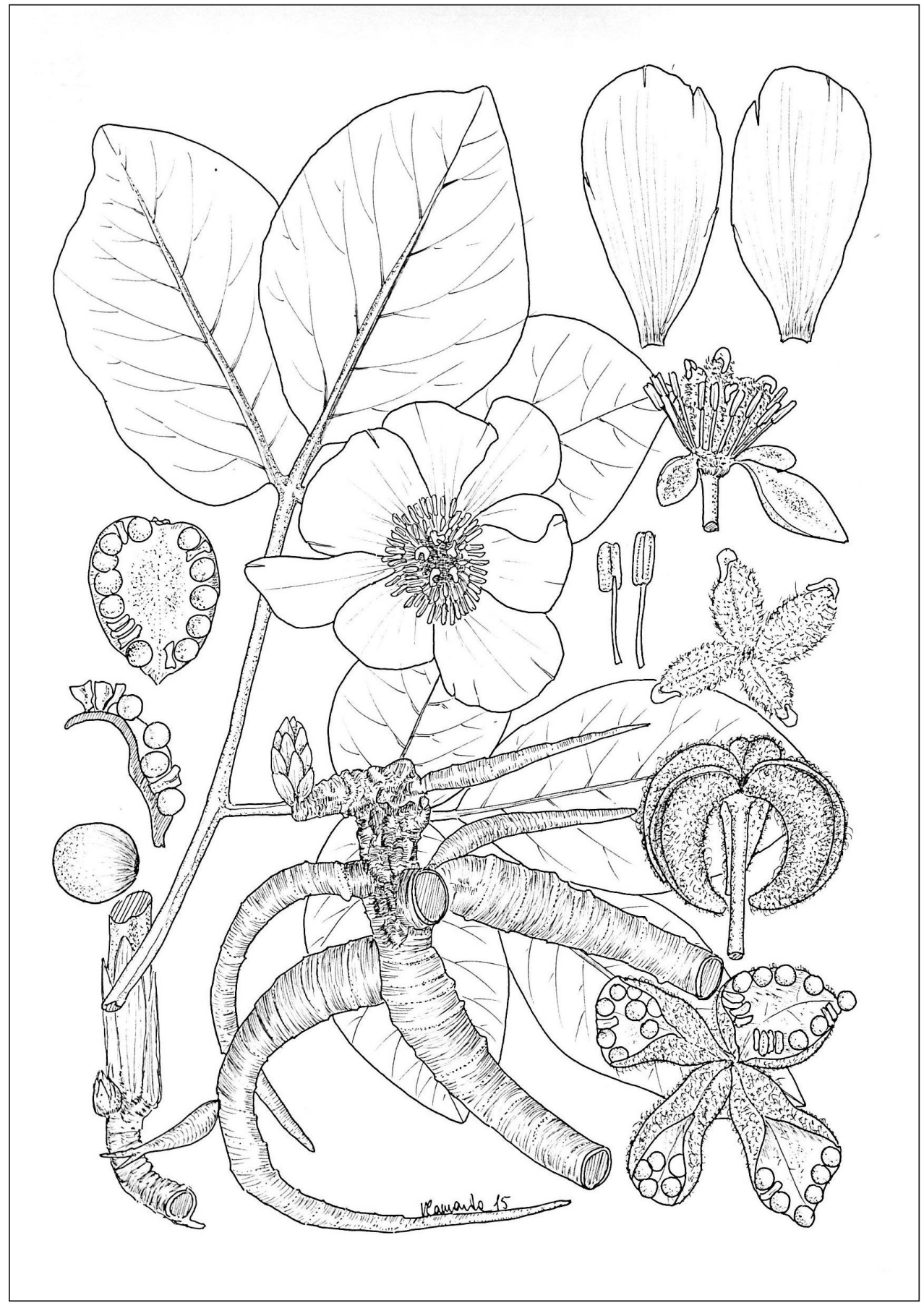

Fig. 1. Paeonia sandrae: Part of leaf/leftlets, petals, flower, stamens and ovary with bracts, close and open carpels $\times 0.3$; four immature carpels and two isolated stamens $\times 0.6$; isolated seed $\times 1.5$. 
ually ovate-lanceolate towards the apex, 6-20 $\times 4-15 \mathrm{~cm}$, usually asymmetrical and progressively reduced in number and size the upper ones, bright green. Flowers terminal, solitary (exceptionally 2); calix with 1-3 bracts cucullate, irregularly shaped and greenish nerves, persistent also in the fruit; petals 6-8 bright pinkish-purple, 6-9 $\mathrm{cm}$ in length and 4-7 cm large, ovate-spatulate, progressively larger towards the apex;. Stamens numerous, filaments purple and anthers yellow 9-10 mm long. Ovary woolly with a recurvate purplish stigma; mature carpels 4-7, $30-70 \mathrm{~mm}$ long and $15-25 \mathrm{~mm}$ in diameter, covered by a woolly hairy, tomentose, whitish grey, with indumentum persistent even in the mature stadium, strongly recurved. Seeds 10-18 in every follicle, spherical 7.4-9.2(10) mm, bright-black fertile ones, pink and angled the sterile other ones.

Paeonia sandrae differs from both P. morisii Cesca \& al. and P. corsica Sieber ex Tausch by glabrous leaflets, petals shape, very woolly carpels indumentum, seeds size and chromosome number. Differs from P. mascula subsp. mascula, for the number of carpels, seeds and leaf shape and size (see Tab. 1).

Life form - Herbaceous, perennial, rhizomatose with tuberose, carrot-shape robust roots, caespitose.

Phenology - Buds are present still at the end of Summer, but arising at the end of January and appearing from soil in the first days of March. Buds include petals, stamens, carpels and leaves from the beginning of their development in February. Flowering begins in May until the first decade of June depending by climatic conditions and altitude. Carpels and seeds mature in August-September and occasionally can persist during the Winter also as dried stems.

Ecology - P. sandrae lives above all in fresh soils of volcanic origin (andosols) and prefers open sunny places, but also in the edge of woods and even in open woods, but in this case with a low vitality.

Range - P. sandrae is widespread in the Marghine-Goceano and Sa Silva hill of Thiesi in the NW-Sardinia, from 500 to $1200 \mathrm{~m}$ a.s.l. (Fig. 2)

Other examined material: Sardinia: Bolotana, Loc. Camorra, Lat. 40 360554-Long. 8 870270, 910 m a.s.1, open wood of Quercus pubescens, 20.VII.2015, I. Camarda s. n., SS!; Thiesi, Loc. Sa Silva-Santu Bainzu, Lat. 40536289 Long. 8 697355, 516 m a.s.1, andosols, open wood of Quercus ilex and Quercus congesta, 6.V.2015, I. Camarda, s. n., SS!; Ibidem, 20.VII.2015, I. Camarda s. n., SS!; Bono. Strada provinciale 43, Loc. Ispadularzu,- Lat. 40457684 Long. 937696, 700 m a.s.1, open wood of Quercus pubescens, 5.V.2015, I. Camarda, s. n., SS!; Ibidem, 20.VII.2015, I. Camarda, SS! 


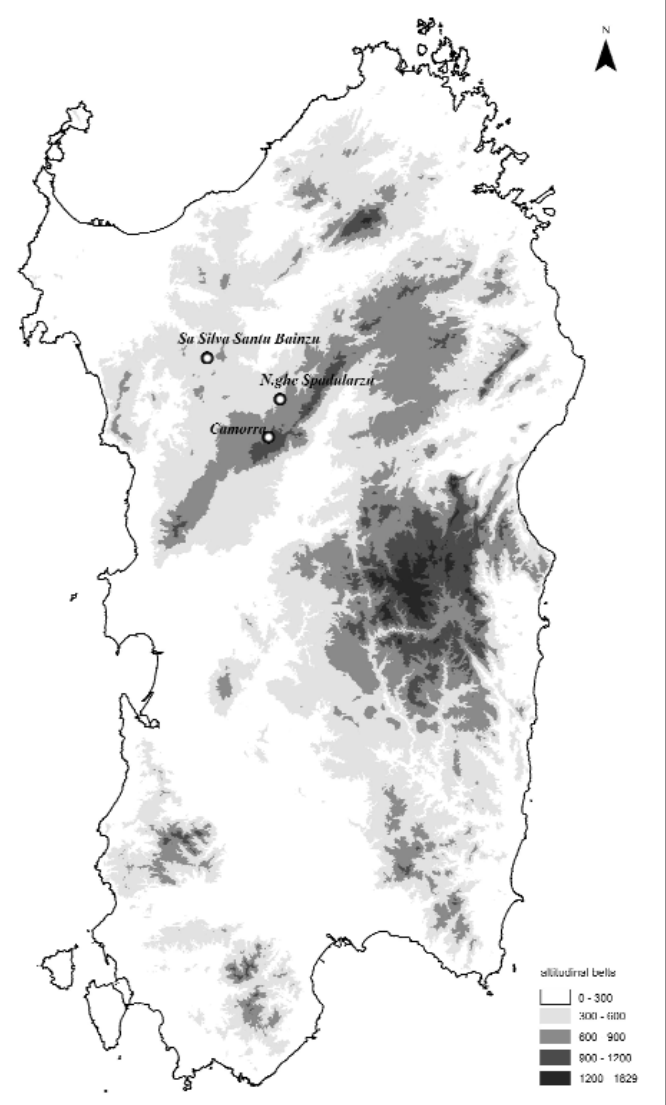

Fig. 2. Distribution of Paeonia sandrae.

\section{Conclusions}

The taxonomic complexity of the Paeonia's Section in the central Mediterranean islands and the different opinions of the authors need further investigation to better clarify the morphological and biological aspects. Arrigoni (2008) according to Cesca \& al. (2001) and Passalacqua \& Bernardo (2004), consider P. morisii, an entity well distinguished from tetraploid $P$. corsica and, otherwise, the tetraploid $P$. sandrae is morphologically very different from both. It shows main affinity with $P$. mascula, but differs in the morphological characters, especially in the number and size of carpels.

Below, the characters comparison of the different peonies: $P$. mascula (Sicily, Madonie, Piano Zucchi), P. morisii (Sardinia, Gennargentu), $\quad P$. corsica (Corsica, Monte Renoso) and $P$. sandrae (Sardinia, Marghine). Similarities and differences useful for species identification are based on keys by Schmitt (2007),

Passalacqua \& Bernardo (2004) and specimens collected or seen by myself (Figs. 3-10).

\section{Key of identification:}

1. Leaves bit coriaceous, hairy beneath

2. Carpels 3-11, grey, weakly hairy or glabrescent, leaflets densely hairy beneath, widely ovate, elliptical or lanceolate

P. morisii

2. Carpels pinkish to purplish, smooth, leaflets sparsely hairy or pubescent, long ovatelanceolate P. corsica

1. Leaves not coriaceous, glabrous 3

3. Carpels 2-5, 2-4 cm long, erect-patent, seeds 6-7 mm P. mascula

3. Carpels 3-7, 3-7 cm long, strongly curvate, seeds $7-9 \mathrm{~mm}$ P. sandrae 
Table 1. Comparison between the species of Paeonia considered in this study.

\begin{tabular}{|l|c|c|c|c|}
\hline Character/Species & P. sandrae & P. mascula & P. morisii & P. corsica \\
\hline Height max. (cm) & 100 & 70 & 60 & 80 \\
\hline Stems/flowers & $2-8$ & - & $3-15$ & $2-6$ \\
\hline Leaves/leaflets beneath. & glabrous & glabrous & pubescent & $\begin{array}{c}\text { subglabr./pubes } \\
\text { cent }\end{array}$ \\
\hline Leaflets (basal leaves) no & $15-25$ & $11-19$ & $9-15$ & $9-23$ \\
\hline Leaflets (basal leaves) & elliptical & ovate & ovate & lanceolate \\
\hline Petals length cm & $6-9$ & $5-7$ & $3-5$ & - \\
\hline Petals shape & $\begin{array}{c}\text { ovate- } \\
\text { spatulate }\end{array}$ & ovate & ovate & ovate \\
\hline Petals color & bright purple & white/red & pink/pale pink & pink to purplish \\
\hline Carpels & $\begin{array}{c}\text { large \& } \\
\text { recurved }\end{array}$ & $\begin{array}{c}\text { large and } \\
\text { court }\end{array}$ & weakly curved & $\begin{array}{c}\text { narrow \& } \\
\text { straight }\end{array}$ \\
\hline Carpels number & $4-7$ & $2-5$ & $5-8(11)$ & $1-5$ \\
\hline Carpels indumentum & very woolly & woolly & hairy/glabrous & glabrous \\
\hline Seeds diameter (mm) & $7-9$ & $6-7$ & $5-6$ & $5-6$ \\
\hline Chrom. number & 20 & 20 & 10 & 20 \\
\hline
\end{tabular}

Synopsis of the genus Paeonia in Sardinia:

Paeonia morisii Cesca, Bernardo \& Passalacqua, (2001)

$=P$. corallina sensu Moris (1837) non Retz (1808)

$=P$. corallina var. pubescens Moris (1837)

$=$ P. corsica Sieber ex Tausch, (1828) pro parte.

$=$ P. mascula subsp. russoi (Biv.) Cullen \& Heywood (1964)

$=$ P. officinalis subsp. corallina (Retz.) Fiori e Paol. (1898)

$=$ P. officinalis var. mascula $($ L.) Fiori (1924)

$=$ P. officinalis var. russii (Biv) Fiori 289 (1924)

$=P$. officinalis subsp. corallina f. angustata Negodi 462 (1931)

= P. officinalis subsp. corallina f. barbaricina Charrier, n. inval. (1963).

= P. officinalis var. triternata (Pall.) f. russoi (Biv.) Fiori (1898).

Paeonia sandrae Camarda

The peonies are widespread in the mountains and hills of Sardinia and often are locally very abundant because, thanks to the presence of alkaloids, are rejected by livestock. At present, the two species are geographically separated (Fig. 2) and were not observed intermediate characters between the two entities. $P$. morisii is indifferent to the pedological substratum, P. sandrae is limited to the volcanic soils (andosols) of the northern central Sardinia. Peony has become a symbol of the Sardinia Region and it is very popular as a garden plant, so it is often subject to withdrawals in nature and, in areas where it is rare, can be in danger of disappearance. Therefore appropriate measures are desirable to ensure their protection and inclusion among the protected species of the Italian flora. 

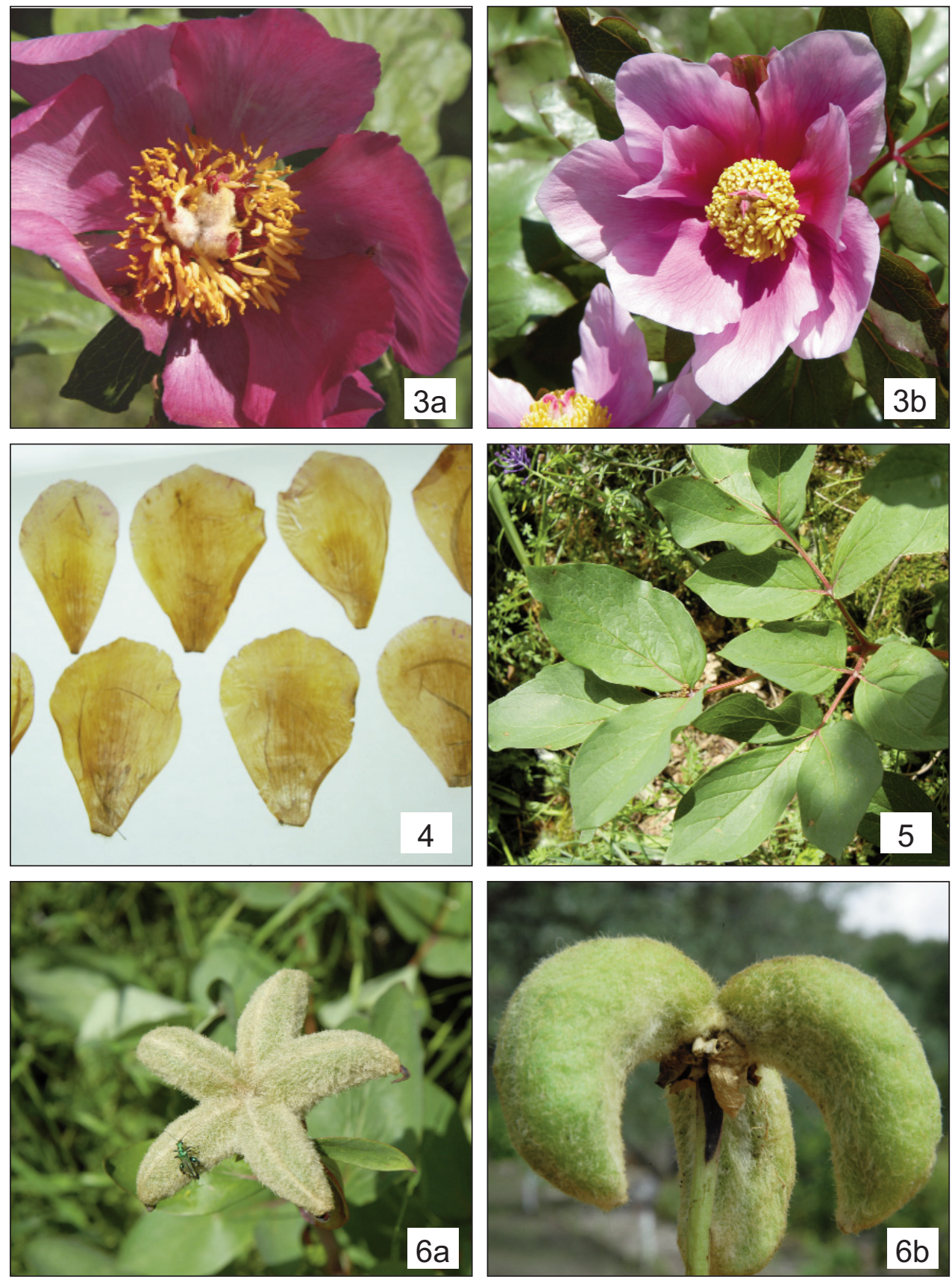

Fig. 3. Flowers of Paeonia sandrae (a, right) and P. morisii (b, left).

Fig. 4. Petal variation in $P$. sandrae.

Fig. 5. Terminal leaf/leaflets of $P$. sandrae.

Fig. 6. Immature (a, left) and mature carpels (b, right) of $P$. sandrae. 

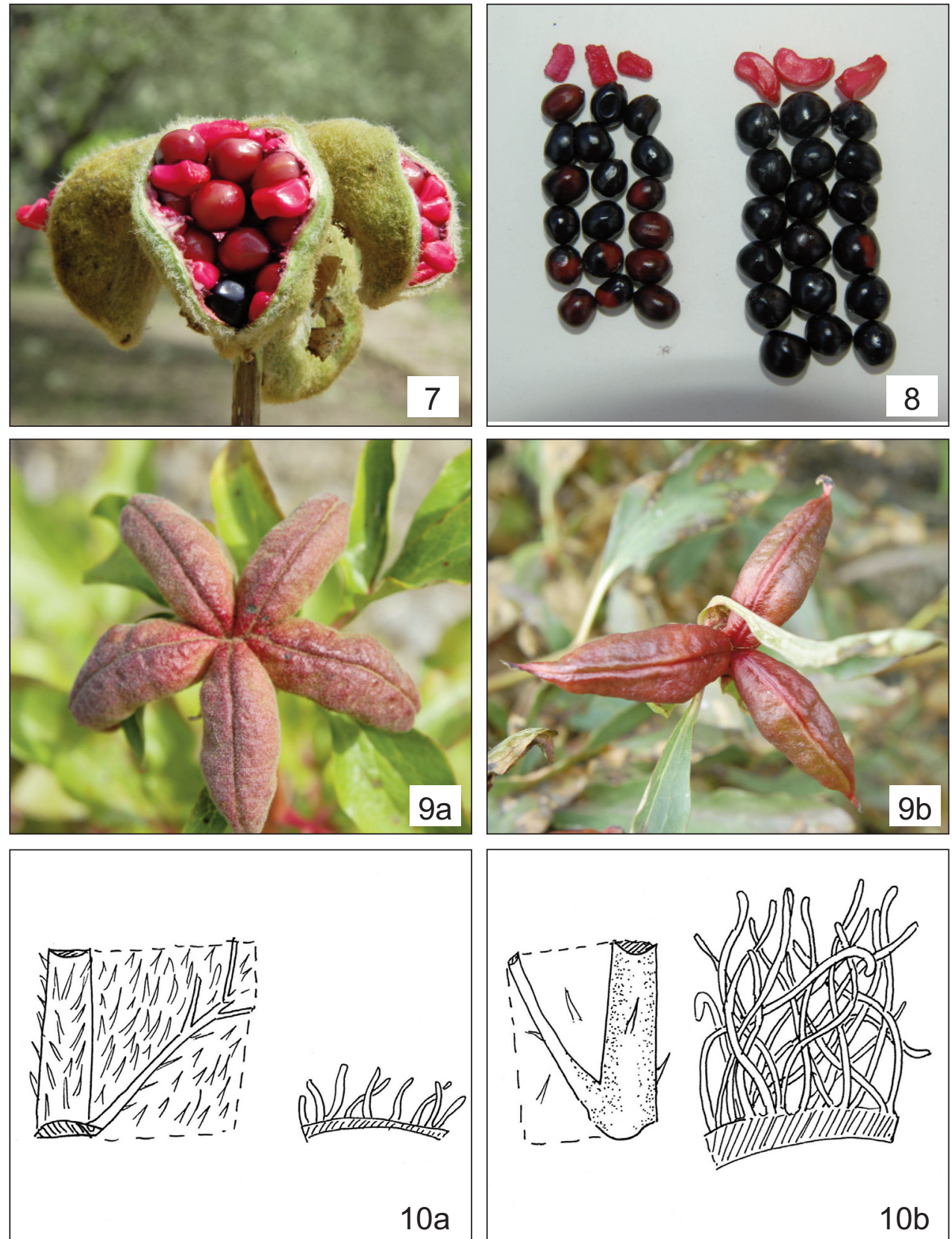

Fig. 7. Open carpels with mature (black) and sterile (red) seeds of $P$. sandrae.

Fig. 8. Comparison between open carpels with mature (black) and sterile (red) seeds of $P$. morisii and $P$. sandrae. The maller open carpels and seeds (left) are of $P$. morisii. The largest (right) are of $P$. sandrae. Fig. 9. Comparison between carpels of $P$. morisii (la, eft) and $P$. corsica (b, right).

Fig. 10. Comparison of hairs of leaves and carpels between P. morisii (a, left) and P. sandrae (b, right). 


\section{Acknowledgements}

I am grateful to dr. Laetitia Hugot, for her cooperation in Corsica, dr. Eric Schmitt for the suggestions about Corsican peonies, prof. Pietro Mazzola for his suggestions and material from Sicily and prof. Enio Nardi, who kindly read the final text.

\section{References}

Arrigoni, P. V. 2006: Paeonia. - Pp. 281-283 in: Flora dell'Isola di Sardegna, 1. - Sassari

Akeroyd, J. R. 1993: Paeonia L. - Pp. 292-294 in: Tutin, T. G., Burges, N. A., Chater, A. O., Edmondson, J. R., Heywood, V. H., Moore, D. M., Valentine, D. H, Walters, S. M. \& Webb, D. A. (eds.), Flora Europaea, $2^{\circ}$ ed., 1. - Cambridge.

Briquet, J. 1910: Paeonia. - Pp. 580-581, 651 in: Prodrome de la Flore Corse, 1. - Geneva \& Basel.

Cesca, G., Bernardo, L. \& Passalacqua, N. G. 2001: Paeonia morisii sp. nov. (Paeoniaceae), a new species from Sardinia. - Webbia 56(2): 229-240.

Charrier, G. 1963: Paeonia officinalis subsp. corallina f. barbaricina. - Giorn. Bot. Ital. 70: 667.

Cullen, J. \& Heywood, V. H. 1964a: Notes on the European Species of Paeonia. - Feddes Repert. 69: 32-35.

— \& — 1964b: Paeonia L. - Pp. 243-244 in: Tutin, T. G., Heywood, V. H., Burges, N. A., Valentine, D. M.,Walters, S. M. \& Webb, D. A.(eds.), Flora Europaea, 1. - Cambridge.

Passalacqua, N. G. \& Bernardo, L. 2004: The genus Paeonia in Italy: taxonomic survey and revision. - Webbia 59(2): 215-2267.

Fiori, A. 1923: Paeonia. - Pp. 689-690 in: Nuova Flora Analitica d'Italia, 1. - Firenze.

Hong, D. Y. 2005: Paeonia in the Mediterranean and Caucasus. - Presentation on the International Peony Symposium in Munich. May 72005.

- 2010: Peonies of the World. Taxonomnic and phytogeography. - Kew.

— \& Wang, X. Q. 2006: The identity of Paeonia corsica Sieber ex Tausch (Paeoniaceae), with special reference to its relationship with P. mascula (L.) Mill. - Fedd. Repert. 117(1-2): 65-84.

Jeanmonod, D. \& Schuessel, A. (eds.) 2006 : Notes et contributions à la flore de Corse. Paeoniaceae - Candollea 61: 126.

Jordan, A. 1903 : Paeonia - P. 38, tav. 32 in : Jordan, A. \& Fourreau, J. 1903 : Icones ad floram europae, 2. - Paris.

Moris, G. G. 1837: Paeonia. - P. 64, t.4 in: Flora Sardoa, 1. - Torino.

Pignatti, S. 1982: Paeoniaceae. - P. 177 in: Flora d'Italia, 1. - Bologna.

Raimondo, F. M., Rossitto, M. \& Ottonello, D. 1983: Numeri cromosomici per la Flora Italiana: 984. - Inform. Bot. Ital. 15:180.

Schmitt, E. 2007 : Révision de la taxonomie des pivoines corses: interprétation biogéographique à l'échelle du bassin méditerranéen et des régions environnantes. - Mém.Ecole Pratiq. Hautes Etud.

Stearn, W. T. \& Davis, P. H. 1984: Peonies of Greece. - Kifissia.

Stern, F. C., 1944: Geographical distribution of the genus Paeonia. - Proc. Lin. Soc. London 13:16-80.

- 1946: A study of the genus Paeonia. - London.

Tausch, I. F. 1828: Bemerkungen ueber einige Arten der Gattung Paeonia. - Flora 11(1): 81-89.

Address of the author:

Ignazio Camarda,

Department of Agriculture, University of Sassari, Via Piandanna, 4, 07100 - Sassari,

Italy. E-mail: icamarda@hotmail.it 